\title{
Justyna Zandberg-Malec
}

Wardyński i Wspólnicy

\section{Prosty język w komunikacji prawniczej - okiem redaktora językowego}

Redaktor językowy tekstów specjalistycznych ma trudne zadanie. Wie na dany temat nieporównanie mniej od autora, a musi korygować jego błędy - i to nie ograniczając się do interpunkcji czy ortografii. Powinien być ambasadorem zarówno autora (pomóc mu jak najskuteczniej wyrazić jego myśl), jak i czytelnika (pomóc mu zrozumieć myśl autora). Oczywiście ma też obowiązki wobec języka jako wartości samej w sobie (albo jako systemu, w którym obowiązują określone reguły).

W moim przekonaniu w wypełnieniu wszystkich tych zobowiązań pomaga redagowanie w duchu prostego języka ${ }^{1}$, czyli z myślą o czytelniku. W odniesieniu do tekstów prawniczych nie jest to zresztą wcale tak rewolucyjne podejście, jak mogłoby się wydawać. Już Bronisław Wróblewski - przytaczając wymagania stawiane w literaturze względem języka prawniczego (czyli „mowy, w której prawnicy wypowiadają się o języku prawnym” [Wróblewski 1948: 140]) - pisał, że język ten powinien być zwięzły, ścisły, łatwo zrozumiały i prosty. Zwłaszcza ta odmiana języka prawniczego, z którą stykają się laicy (w ówczesnych warunkach - język sądowy), powinna być zrozumiała i zbliżona do języka potocznego (teraz powiedzielibyśmy raczej: do języka ogólnego) [Wróblewski 1948: 183].

Wytyczne te są w dużej mierze zbieżne z zaleceniami prostego języka. Zgodnie $z$ definicją przyjętą przez International Plain Language Federation tekst jest napisany prostym językiem, jeśli słowa, struktura i układ graficzny

1 Prosty język jest ugruntowanym już polskim odpowiednikiem terminu plain language [Piekot, Zarzeczny, Moroń 2019: 197]. Nie należy go oczywiście mylić ze znanym w językoznawstwie terminem język prosty (język pogranicza, mieszanka starego języka ruskiego i polskiego). 
pomagają zakładanym odbiorcom łatwo znaleźć potrzebne informacje, zrozumieć je i zrobić z nich użytek. Do tego dochodzą szczegółowe wytyczne dotyczące długości zdania, szyku wyrazów czy obecności w tekście elementów nawigacyjnych, takich jak śródtytuły ${ }^{2}$. Przede wszystkim jednak trzeba się zastanowić, kto będzie odbiorcą tekstu i w jakim stopniu należy ułatwić mu lekturę.

Teksty, które od ponad 10 lat redaguję w kancelarii prawnej, w dużej mierze mieszczą się w kategorii „odmiany języka prawniczego, z którą stykają się laicy" - ale laicy ponadprzeciętnie zainteresowani prawem. Są to przede wszystkim teksty o charakterze popularyzatorskim, przeznaczone do publikacji na portalu internetowym o tematyce prawnej. Ich docelowym odbiorcą jest potencjalny klient kancelarii, przedsiębiorca lub prawnik wewnętrzny przedsiębiorstwa, szukający informacji na temat jakiegoś konkretnego problemu prawnego. W realiach kancelarii prawnej nie chodzi więc o to, by uzyskać tekst zrozumiały dla każdego. Taka potrzeba istnieje w przypadku tekstów skierowanych ,do wszystkich”, takich jak np. pouczenia dla zatrzymanych czy świadków ${ }^{3}$.

Nawet jednak jeśli odbiorcą jest specjalista, troska o zrozumiałość - a nie tylko o poprawność językową - będzie zaletą, a nie wadą tekstu. Potwierdzeniem niech będą badania przeprowadzone w 1987 roku w Michigan na grupie kilkuset sędziów i adwokatów. W badaniu - które przedstawiono ankietowanym jako „badanie trendów językowych u przedstawicieli zawodów prawniczych" - poproszono prawników o wskazanie preferowanej wersji sześciu akapitów. Były one sformułowane albo zgodnie z zasadami prostego języka, albo w sposób typowy dla angielskiego języka prawniczego (rzeczowniki odsłowne, strona bierna, długie zdania, wtrącenia, dublety językowe, archaiczne słowa, słowa długie i rzadkie). W teście A/B 80\% adwokatów i 85\% sędziów wybrało fragmenty sformułowane prostym językiem. Badania zostały powtórzone kil-

2 Ponieważ artykuł dotyczy bardziej praktyki niż teorii, nie wyliczam tu szczegółowo tych zasad ani ich źródeł. Sama zetknęłam się z ruchem plain language w jego wersji anglojęzycznej, której rzecznikami są organizacje Center for Plain Language, Clarity i PLAIN, a od niedawna również łącząca je wszystkie International Plain Language Federation (https:// www.iplfederation.org/ [dostęp: 4 stycznia 2021]). Później zetknęłam się oczywiście z pracami dr Mileny Hadryan, prof. dr. hab. Włodzimierza Gruszczyńskiego oraz dr. hab. Tomasza Piekota. Na potrzeby swojej praktyki redaktorskiej opracowałam jednak własną listę zasad, którą podaję niżej (w postaci pytań, które zadaję sobie w trakcie pracy). Nie poczuwam się oczywiście do autorstwa żadnej z tych zasad. Po wielu latach praktyki nie umiem jednak wskazać, gdzie po raz pierwszy zetknęłam się z każdą z nich.

3 Przykład takiego tekstu - przeredagowane w duchu prostego języka pouczenia dla zatrzymanego - zob. Zandberg-Malec, Pietryka, Kozłowska 2020. 
kakrotnie, z tym samym rezultatem: preferencja dla tekstów sformułowanych prostym językiem była na poziomie co najmniej 80\% [Kimble 2011:3-13].

$\mathrm{Na}$ mniejszą skalę potwierdziłam tę preferencję w kancelarii, w której pracuję. Przygotowałam ankietę, którą wysłałam do prawników i asystentek w kancelarii; wypełniło ją 45 osób. Jedno z czterech pytań brzmiało: jak istotne jest, żeby pisane przez prawników pisma były zrozumiałe, skuteczne, poprawne językowo, zwięzłe, wyczerpujące, eleganckie, sformalizowane? Okazało się, że prawnicy cenią zrozumiałość równie wysoko jak skuteczność - a nawet trochę wyżej, choć różnica jest zapewne statystycznie nieistotna („Tekst musi być zrozumiały”: bardzo istotne dla 41 respondentów, istotne dla 4; „Tekst musi być skuteczny": bardzo istotne dla 40 respondentów, istotne dla 5)4.

Jedną z przyczyn tak wysokiej oceny zrozumiałości jest niewątpliwie brak czasu - zarówno po stronie nadawców, jak i odbiorców (sędziów, klientów). Tekstów prawniczych raczej nie czyta się dla przyjemności; czyta się je, by jak najszybciej uzyskać odpowiedź albo wyrobić sobie opinię na dany temat. Dlatego czytelnik z ulgą przyjmie tekst, którego nie trzeba czytać dwa razy, żeby zrozumieć jego sens. $Z$ takim właśnie założeniem przystępuję zwykle do redagowania tekstów prawniczych.

Pracując nad tekstem, wprowadzam poprawki dwojakiego rodzaju: strukturalne i językowe (nie zawsze oczywiście; często tekst jest bez zarzutu pod względem struktury i wystarczy korekta językowa; rzadziej mam do czynienia z sytuacją odwrotną). Zmiany strukturalne wymagają jednak dobrego rozumienia tekstu. Dlatego czasem łatwiej jest zacząć od pozornie kosmetycznych i mało znaczących zmian językowych: podzielenia długich zdań na krótsze, zamiany rzeczowników odsłownych na czasowniki, uporządkowania struktury zdania. Często takie zabiegi ujawniają sens hermetycznego z pozoru tekstu i odsłaniają jego niedociągnięcia strukturalne: powtórzenia, niefortunną kolejność informacji, niewłaściwe łączniki logiczne między poszczególnymi fragmentami. Można wtedy z powodzeniem wprowadzać poważniejsze zmiany: zmieniać kolejność, wykreślać, dopisywać.

Wszystkie takie zmiany należy oczywiście bezwzględnie ustalać $\mathrm{z}$ autorem. Nawet z pozoru kosmetyczna poprawka może bowiem zmienić sens specjalistycznego tekstu. Jeśli jednak zadaliśmy sobie dość trudu, żeby przeniknąć zamysł i intencje autora, możemy osiągnąć najwyższą chyba satysfakcję dostępną redaktorowi: usłyszeć „dokładnie o to mi chodziło”.

Co ciekawe, niepełna znajomość dziedziny, której dotyczy tekst, może być zaletą redaktora. Nie wypełniamy niejasności wiedzą pozatekstową. Nie

4 Pełen opis badania w: Zandberg-Malec 2020. 
ignorujemy skrótów myślowych. Łatwiej nam dostrzec niedociągnięcia językowe i logiczne - czyli dokładnie te miejsca, które mogą sprawić trudność czytelnikowi.

\section{Porządki strukturalne}

Przystępując do porządków strukturalnych, zadaję sobie następujące pytania:

- Czy czytelnik może się szybko zorientować, o czym jest tekst i jaki jest jego główny przekaz?

- Czy ma komplet informacji i czy są one dla niego interesujące?

- Czy może przeskanować tekst wzrokiem (czy w tekście są śródtytuły lub inne elementy nawigacyjne)?

- Czy autor nie zakłada zbyt dużej wiedzy czytelnika?

- Czy informacje są wprowadzane w logicznej kolejności (znane nowe)?

- Czy tekst jest podzielony na krótkie akapity?

- Czy pierwsze (lub ostatnie) zdanie akapitu niesie główną treść?

- Czy jasne są relacje logiczne między poszczególnymi zdaniami lub częściami zdania?

Ostatni punkt jest - jak wynika z moich obserwacji - najczęstszą chyba przyczyną niezrozumiałości tekstu i może być najtrudniejszy do naprawienia. Najwygodniej wówczas skontaktować się z autorem. Czasem jednak to niemożliwe. Wówczas redaktor jest zdany na własną domyślność i sięganie do źródeł. Z mojego doświadczenia wynika, że takie zadanie jest wprawdzie czasochłonne, ale może przynieść dobre rezultaty.

Prześledźmy to na przykładzie. Poniższy fragment pochodzi z artykułu omawiającego nowelizację ustawy Prawo budowlane. Jedną ze zmian wprowadzonych nowelizacją było zawężenie kręgu podmiotów, które mogą być stroną w postępowaniu o wydanie pozwolenia na budowę. Autorka pozytywnie ocenia tę zmianę, gdyż wcześniej prawo było niejasne, co powodowało rozbieżności w orzecznictwie. Na dowód autorka przytacza cztery orzeczenia sądów. Poniższy fragment omawia jedno $\mathrm{z}$ nich:

Przykładowo WSA w Poznaniu ${ }^{1}$ zanegował możliwość uznania za stronę właściciela nieruchomości sąsiedniej, na której dało się odczuć skutki, uciążliwości spowodowane funkcjonowaniem nowobudowanego obiektu. WSA stwierdził, że nie wystarczy powołać się na art. 140 kodeksu cywilnego aby wykazać swoje uprawnienie. Takie rozumienie odwołuje się bowiem do oddziaływania faktycznego, którego nie można utożsamiać z oddziaływaniem polegającym na wprowadzaniu ograniczeń w rozumieniu art. 3 pkt 20 prawo budowlanego. 
Do przepisów odrębnych, w rozumieniu art. 3 pkt 20 ustawy Prawo budowlane, należą przepisy rozporządzenia określającego warunki techniczne, jakim powinny odpowiadać budynki i ich usytuowanie, ale także przepisy z zakresu ochrony środowiska, ochrony zabytków, ochrony przyrody, prawo wodne, prawo lotnicze, przy czym przepis art. 140 kodeksu cywilnego nie stanowi wystarczającej podstawy prawnej.

Czytelnik niniejszego artykułu, konfrontując się ze specjalistycznym tekstem prawniczym, ma prawo czuć się zagubiony. Podobnie jednak mógłby się poczuć czytelnik artykułu, z którego ten fragment pochodzi. Dotyczy on bowiem całkowicie nowego aspektu sprawy. Wcześniej w artykule nie było mowy o „art. 140 kodeksu cywilnego" i nie można zakładać, że czytelnik zna jego treść. We fragmencie tym występują problemy różnej wagi, które wymieniam tu w kolejności, w jakiej się pojawiają:

a) na początku jest przypis (tu niecytowany), w którym znajduje się wyłącznie sygnatura sprawy. Niepotrzebnie odwraca to uwagę czytelnika. Wprawdzie dobrą zasadą jest przenoszenie do przypisów elementów niekoniecznych do śledzenia toku wywodu, tu jednak tekst jest na tyle niezrozumiały, że czytelnik mógł się spodziewać, że w przypisie znajdzie jakieś wyjaśnienie, i niepotrzebnie oderwać się od lektury;

b) dało się odczuć skutki, uciążliwości spowodowane - nie jest jasne, czy skutki są synonimem uciążliwości. Termin uciążliwość pojawia się bowiem po raz pierwszy w tym tekście i czytelnik nie miał czasu się oswoić z jego prawnym znaczeniem;

c) nowobudowanego - błąd ortograficzny;

d) nie wystarczy powołać się na art. 140 kodeksu cywilnego aby wykazać swoje uprawnienie - nie wiadomo, jaka jest treść art. 140 k.c. i czemu właściciel nieruchomości sąsiedniej miałby się na niego powoływać; nie wiadomo też, jakie swoje uprawnienie miałby wykazywać w ten sposób; brakuje też oczywiście przecinka przed aby;

e) Takie rozumienie odwołuje się bowiem do oddziaływania faktycznegonie wiadomo, jakie rozumienie i czemu miałoby się odwoływać do oddziaływania faktycznego;

f) Do przepisów odrębnych [...] należa - nie wiadomo, czemu autorka postanawia nieoczekiwanie wyliczyć przepisy odrębne - jaki jest ich związek ze sprawą;

g) przy czym przepis art. 140 kodeksu cywilnego nie stanowi wystarczajacej podstawy prawnej-znów: nie wiadomo, co jest treścią art. 140 k.c. i do czego nie stanowi on wystarczającej podstawy prawnej. 
Zacytowany fragment wyraźnie odbiegał poziomem zrozumiałości od reszty artykułu, co ma proste wyjaśnienie. Autorka, zamiast sparafrazować wyrok, przytoczyła jego wybrany akapit, uznając, że dobrze podsumowuje on stanowisko sądu. Nie wzięła jednak pod uwagę, że akapit ten został wyrwany z kontekstu i przedstawiony czytelnikowi, któremu brakuje wypunktowanych powyżej informacji.

Dlatego należało:

a) wyjaśnić, że spór dotyczył tego, czy sąsiad, który z powodu budowy doświadczał uciążliwości (termin fachowy), może być stroną w postępowaniu;

b) przytoczyć treść art. 140 k.c. (prawo do korzystania ze swojej własności zgodnie z jej przeznaczeniem);

c) wyjaśnić, o jakie uprawnienie chodziło (prawo bycia stroną w postępowaniu);

d) wyjaśnić, że uciążliwość jest oddziaływaniem faktycznym, a stroną zdaniem sądu - może być podmiot doznający ograniczeń prawnych $n a$ podstawie przepisów odrębnych (i tu wyliczyć te przepisy);

e) opatrzyć fragment śródtytułem podsumowującym stanowisko sądu (pod tym śródtytułem zostały omówione dwa orzeczenia; kolejne dwa, prezentujące odmienny pogląd, zostały omówione pod śródtytułem „Uciążliwość uzasadnia przyznanie statusu strony?”);

f) przenieść sygnaturę akt z przypisu do tekstu głównego - krótki tekst w nawiasie nie zaburza toku lektury; czytelnik może go albo pominąć, albo - gdyby był ciekaw - łatwo wyszukać ten wyrok w bazie orzeczeń.

Efekt tych działań na tekście znajduje się poniżej.

\section{Uciążliwość nie uzasadnia przyznania statusu strony?}

Przykładowo WSA w Poznaniu w wyroku z 9 lipca 2020 r. (II SA/Po 159/20) zanegował możliwość uznania za stronę właściciela nieruchomości sąsiedniej, na której dało się odczuć skutki (uciążliwości) spowodowane funkcjonowaniem nowo budowanego obiektu. Sąsiad wskazywał bowiem na oddziaływanie faktyczne, którego nie można utożsamiać z oddziaływaniem polegającym na wprowadzaniu ograniczeń na podstawie przepisów odrębnych, o czym mówi art. 3 pkt 20 Prawa budowlanego. Do przepisów odrębnych, w rozumieniu art. 3 pkt 20 ustawy Prawo budowlane, należą przepisy rozporządzenia określającego warunki techniczne, jakim powinny odpowiadać budynki i ich usytuowanie, ale także przepisy z zakresu ochrony środowiska, ochrony zabytków, ochrony przyrody, prawa wodnego czy prawa lotniczego. Jak stwierdził WSA, aby uzyskać status strony w sprawie, nie wystarczy 
powołać się na art. 140 k.c. (prawo do korzystania ze swojej własności zgodnie z jej przeznaczeniem).

Po konsultacji z autorką okazało się, że taki miał być właśnie wydźwięk cytowanego akapitu i w takim kształcie został opublikowany.

Konieczność tak dogłębnych zmian (na szczęście) zdarza się rzadko, chyba że celem jest całkowite przeredagowanie tekstu w celu dostosowania go do innego typu odbiorcy (zob. przypis 2). Zdecydowanie częściej w tekście potrzebne są po prostu porządki językowe.

\section{Porządki językowe}

Przystępując do porządków językowych - poza oczywistym w pracy redaktora tropieniem literówek i niezgodności gramatycznych - zadaję sobie następujące pytania:

- Czy zdanie jest tak krótkie, jak się da?

- Czy zachowany jest naturalny szyk (podmiot, orzeczenie, dopełnienie)?

- Czy nie ma niepotrzebnie trudnych słów?

- Czy potrzebne a trudne terminy zostały wyjaśnione?

- Czy podmiot i orzeczenie są blisko siebie i blisko początku zdania?

- Czy podmiotem jest człowiek/firma, a nie instytucja prawna?

- Czy są frazy/słowa, które można wyciąć bez szkody dla treści?

- Czy są rzeczowniki odsłowne, które można zmienić na czasowniki?

- Czy stronę bierną można zmienić na czynną?

- Czy wyrazy powiązane znaczeniowo stoją tak blisko siebie, jak to możliwe?

- Czy nie ma niezamierzonych związków składniowych?

- Czy nie ma długich ciągów rzeczownikowych?

- Czy jest jasne, co się kryje pod zaimkiem?

- Czy „najcięższe jest na końcu”?

Poniżej przedstawiam przykłady obrazujące wybrane zasady.

\section{Przykład 1: długość zdania, brak paralelizmu składniowego, zbędne słowa}

Jednym z zaleceń prostego języka jest pisanie krótkich zdań. Jako pożądaną długość zdań wskazuje się 15-20 wyrazów (zaleca się też, żeby różnicować długość zdań, aby uniknąć monotonii). W tekstach prawniczych trudno jest jednak uzyskać tę długość. Nie należą do rzadkości zdania złożone z 60, albo i 80 wyrazów. Rozsądnym kompromisem wydaje mi się ok. 30 wyrazów. 
Redagując, staram się trzymać zasady, że zdanie powinno być możliwe do ogarnięcia myślą. Czytelnik nie powinien wracać wzrokiem do początku, żeby sobie przypomnieć, o czym właściwie jest mowa. Dobrym testem jest też możliwość odczytania zdania na głos na jednym oddechu.

Poniższe zdanie, złożone z 44 wyrazów, nie należy do najdłuższych. Z paru powodów jest ono jednak dość trudne w odbiorze. Czytelnik po jednorazowej lekturze mógłby mieć kłopot ze zrelacjonowaniem komuś jego treści. Trudno byłoby też je swobodnie odczytać na głos.

W praktyce mogą pojawić się problemy związane z wykazaniem w jakiej dacie zakończona została budowa samowolnie zrealizowanego obiektu, ale też jak traktować ewentualne późniejsze roboty budowlane przy takim obiekcie, które również były wykonywane w warunkach samowoli przed upływem 20 lat od dnia wszczęcia postępowania.

Przede wszystkim rzuca się w oczy brak paralelizmu składniowego. W zdaniu jest mowa o „problemach związanych z wykazaniem x” (gerundium) i ,problemach, jak traktować y" (bezokolicznik). Rozwiązaniem mogłoby więc być przeredagowanie zdania, tak by oba człony miały analogiczną strukturę (np. ,problemy z wykazaniem x i zakwalifikowaniem y" (dwa razy gerundium) lub „problem, jak wykazać x i jak traktować y” (dwa razy bezokolicznik)). Jednak opis zarówno $\mathrm{x}$, jak i y jest dość rozbudowany. Na dodatek prosty język zaleca stosowanie się do zasady ,jedno zdanie - jedna myśl”. Stąd decyzja, żeby rozbić zdanie na dwa zdania, z których pierwsze dotyczy kłopotów z wykazaniem daty zakończenia budowy (można by się zastanawiać, czy faktycznie chodzi o wykazanie, czy raczej o określenie tej daty), a drugie - prawnej kwalifikacji ewentualnych późniejszych robót budowlanych przy samowolnie zrealizowanym obiekcie.

Mniejszej wagi problemem było rozpoczęcie zdania od pustego znaczeniowo zwrotu $w$ praktyce (fraza, którą można usunąć bez szkody dla treści; problemy zwykle pojawiają się $w$ praktyce) i niepotrzebnie urzędowego zwrotu w jakiej dacie (być może autorowi kiedy wydało się nazbyt potoczne i nieprzystające do stylu prawniczego). W zaproponowanej redakcji oba te zwroty zostały usunięte, co zostało zaakceptowane przez autora. W efekcie zamiast 44-wyrazowego zdania dotyczącego dwóch różnych problemów mamy dwa zdania, liczące 12 i 28 wyrazów, z których każde dotyczy jednego problemu. Zwiększyła się też „potoczność” słownictwa (trudno, kiedy, nie jest jasne), co w tekście kierowanym do dość szerokiego odbiorcy wydaje się pożądane. 
Czasem trudno też będzie wykazać, kiedy została zakończona budowa samowolnie zrealizowanego obiektu. Nie jest też jasne, jak traktować ewentualne późniejsze roboty budowlane przy takim obiekcie, które również były wykonywane w warunkach samowoli przed upływem 20 lat od dnia wszczęcia postępowania.

\section{Przykład 2: odległość podmiotu od orzeczenia}

Kolejnym zaleceniem prostego języka jest unikanie wtrąceń i stawianie wyrazów powiązanych logicznie blisko siebie. Poniżej cytowane zdanie nie realizuje tych zasad, co utrudnia jego zrozumienie. Niejasność potęgują jeszcze literówki, które utrudniają odkodowanie sensu (którzy uwagi zamiast którzy z uwagi; nie dysponuja dokumentacja dotyczaca zamiast nie dysponuja dokumentacja dotyczaca).

Dla osoby znającej zasady przestankowania utrudnieniem jest też brak przecinków wyznaczających początek i koniec zdania podrzędnie złożonego. Wydaje się jednak, że ich brak nie przeszkadza osobom, które tych zasad nie znają (ciekawe mogłyby być badania w tym zakresie). Ja jednak, pracując nad tekstem, często wstawiam brakujące przecinki, nawet jeśli na dalszym etapie przeredaguję zdanie - pomaga mi to odkodować strukturę i sens zdania i podjąć decyzję o potrzebie poważniejszych zmian.

Największym problemem w poniższym zdaniu jest odległość między podmiotem a orzeczeniem - oddzielają je 24 wyrazy będące rozbudowanym określeniem podmiotu.

Wydaje się, że wielu właścicieli nie tylko nieruchomości samowoli, ale również tych którzy uwagi na znaczący upływ czasu nie dysponują dokumentacja dotycząca budowy i oddawania takich budynków do użytkowania będzie chciało skorzystać z nowych regulacji.

Oczywistym rozwiązaniem jest więc przybliżenie podmiotu i orzeczenia. W tym konkretnym przypadku, ze względu na rozbudowane określenie podmiotu, wymagało to inwersji: na początku mamy dopełnienie (z nowych regulacji), potem orzeczenie (będzie chciało skorzystać) i dopiero potem podmiot (wielu wtaścicieli) z określeniami.

Wydaje się, że z nowych regulacji będzie chciało skorzystać wielu właścicieli - nie tylko samowolnie wybudowanych obiektów, ale również tych, którzy z uwagi na upływ czasu nie dysponują dokumentacją dotyczącą budowy i oddawania takich budynków do użytkowania. 
Uważny czytelnik zwróci uwagę, że określenia te nie są paralelne składniowo. Pierwsze określenie jest przydawką dopełniaczową (właściciele samowolnie wybudowanych obiektów), a drugie - przydawkowym zdaniem podrzędnym (wtaściciele, którzy z uwagi na uptyw czasu nie dysponuja dokumentacja dotyczaca budowy i oddawania takich budynków do użytkowania). Nie twierdzę, że przedstawiona propozycja jest najlepszą realizacją tej treści (redaktor pracuje często w dużym tempie i nie ma czasu na spokojne cyzelowanie tekstu). Jest ona jednak według mnie znacząco lepsza od oryginału również z tego względu, że najcięższy człon zdania znajduje się na końcu, więc nie obciąża niepotrzebnie zasobów poznawczych czytelnika (jak pisze Steven Pinker, „lekkie przed ciężkim” to jedna z najstarszych zasad obowiązujących w językoznawstwie, odkryta w IV w p.n.e. przez Paniniego, twórcę pierwszej gramatyki sanskrytu [Pinker 2016: 148]).

\section{Przykład 3: wyliczenie}

Przeróbka kolejnego zdania jest przykładem zastosowania jednej z najbardziej znanych zasad prostego języka: zmiany wyliczenia wewnątrz zdania na listę wypunktowaną.

Nowe regulacje jasno określają przypadki kiedy wydany być może nakaz rozbiórki, zawężając go do przypadków niezłożenia lub wycofania wniosku o legalizację, nieprzedłożenia dokumentów legalizacyjnych, nieusunięcia nieprawidłowości w dokumentacji legalizacyjnej lub kontynuowania budowy pomimo wydania nakazu jej wstrzymania.

Przy okazji długie zdanie zostało podzielone na dwa krótsze, a rzeczowniki odsłowne zostały zamienione na czasowniki w formie osobowej. Wymagało to określenia wykonawcy czynności, w tym przypadku ,inwestora, właściciela lub zarządcy budynku" (informacja ta znajdowała się w innej części tekstu). Usunięto też niefortunne sformułowanie nakaz rozbiórki zawężony do przypadków x $i$ y.

Nowe regulacje zawężają listę przypadków, w których może być wydany nakaz rozbiórki. Nakaz ten zostanie wydany tylko wtedy, gdy inwestor, właściciel lub zarządca budynku:

- nie złożył wniosku o legalizację lub wycofał taki wniosek,

- nie przedłożył dokumentów legalizacyjnych,

- nie usunął nieprawidłowości w dokumentacji legalizacyjnej, 
- kontynuował budowę pomimo wydania nakazu jej wstrzymania.

Co ciekawe, autor zdania, akceptując redakcję, dopisał do tej listy piąty punkt: „nie zapłacił opłaty legalizacyjnej”. Pokazuje to, że prosty język ułatwia zadanie nie tylko czytelnikowi, ale również autorowi: pomaga mu wykryć niedociągnięcia własnego tekstu.

\section{Przykład 4: niezamierzony związek składniowy}

Ostatni przykład dotyczy niezamierzonego związku składniowego, który może utrudnić prawidłowe odkodowanie sensu zdania, a nawet wywołać niezamierzony efekt komiczny. Powodem dwuznaczności jest homonimia zaimka które w liczbie pojedynczej i rodzaju nijakim oraz w liczbie mnogiej i rodzaju niemęskoosobowym.

Ujmując w skrócie stan faktyczny, odnosił się on do pozwolenia na rozbudowę budynku mieszkalnego jednorodzinnego wraz ze zmianą konstrukcji dachu i budową kanalizacji sanitarnej ze zbiornikiem na ścieki, które po wydaniu i rozpoczęciu prac budowlanych zostało $\mathrm{w}$ ich toku zakwestionowane przez organy nadzoru budowlanego.

Dodatkowym utrudnieniem jest niepotrzebne rozpoczęcie zdania od frazy imiesłowowej (Ujmując w skrócie stan faktyczny, odnosit się on... zamiast po prostu Stan faktyczny odnosit się...). Dalej czytamy o pozwoleniu na rozbudowę budynku z budową kanalizacji na ścieki, które po wydaniu i rozpoczęciu prac budowlanych... Ponieważ zakładamy, że zaimek odnosi się do ostatniego rzeczownika o określonym rodzaju i liczbie, odczytujemy które jako odnoszące się do ścieków. Dlatego pewnym zaskoczeniem może być rozwinięcie zdania w postaci frazy zostato $w$ ich toku zakwestionowane przez organy nadzoru. Mamy tu do czynienia z zawiedzionym oczekiwaniem czytelnika, koniecznością powrotu wzrokiem do początku zdania, a niewykluczone, że i z rozbawieniem związanym z rzekomym ,zakwestionowaniem ścieków przez organy nadzoru". Wskazane jest więc przeredagowanie zdania, żeby nie było wątpliwości, co mianowicie zostało zakwestionowane.

Stan faktyczny odnosił się do pozwolenia na rozbudowę budynku mieszkalnego jednorodzinnego wraz ze zmianą konstrukcji dachu i budową kanalizacji sanitarnej ze zbiornikiem na ścieki. Już po rozpoczęciu prac budowlanych pozwolenie to zostało zakwestionowane przez organy nadzoru budowlanego. 


\section{Podsumowanie}

Zasady prostego języka doskonale znajdują zastosowanie w komunikacji prawniczej. Nawet powierzchniowa redakcja w tym duchu zwiększa zrozumiałość tekstu. Co więcej, z moich doświadczeń wynika, że autorom odpowiadają wprowadzane zmiany. Niezmiernie rzadko kwestionują oni proponowaną przeróbkę tekstu. Zwykle zdarza się to, gdy źle odkodowałam sens zdania - co mogłoby się przytrafić również docelowym czytelnikom. Wspólnie wypracowujemy wtedy kolejną wersję danego fragmentu.

Idealnym rozwiązaniem byłoby oczywiście, gdyby autorzy od początku tworzyli teksty zgodne z zasadami prostego języka. Na przeszkodzie stoją tu jednak wieloletnie niekiedy nawyki, przekonanie, że język prawniczy wymaga bezosobowości i nasycenia rzeczownikami, klątwa wiedzy (czyli trudności $\mathrm{z}$ rozpoznaniem, że czytelnik nie wie tego co autor) oraz wspomniany wcześniej brak czasu. Jak wiadomo bowiem, napisanie zwięzłego, zrozumiałego tekstu bywa naprawdę czasochłonne.

\section{Bibliografia}

Kimble Joseph (2011), Strike Three for Legalese, w: tenże, Lifting the Fog of Legalese. Essays on Plain Language, Durham.

Piekot Tomasz, Zarzeczny Grzegorz, Moroń Ewelina (2019), Standard „plain language" w polskiej sferze publicznej, w: Lingwistyka kryminalistyczna. Teoria i praktyka, red. Monika Zaśko-Zielińska, Krzysztof Kredens, Wrocław, s. 197-214.

Pinker Steven (2016), Piękny styl. Przewodnik człowieka myślacego po sztuce pisania XXI wieku, Sopot.

Wróblewski Bronisław (1948), Język prawny i prawniczy, Kraków.

Zandberg-Malec Justyna (2020), Prawnicy chcieliby pisać prosto, ale nie mają czasu, „The Clarity Journal”, nr 81, s. 19-21.

Zandberg-Malec Justyna, Pietryka Artur, Kozłowska Maria (2020), Zrozumiałe pouczenia dla zatrzymanych, „Co do zasady”, 10 grudnia, https://codozasady.pl/p/zrozumiale-pouczenia-dla-zatrzymanych [dostęp: 4 stycznia 2021].

Justyna Zandberg-Malec

\section{Plain Language in Legal Communication - in the Eye of the Editor}

The article discusses the practical use of plain language rules in editing law-related texts. The author believes that it is possible and worth the effort to write legal texts 
in accordance with the rules of plain language, i.e. with the expected reader in mind, giving examples of rewritten sentences taken from the articles for an online law portal. The author divides the processes in terms of 'structural order' and 'linguistic order' and shows that even cosmetic editing in the spirit of plain language, without affecting the text's structure, improves its intelligibility.

KEYWORDS: plain language; legal language; text intelligibility.

mgr Justyna Zandberg-Malec [ORCID: 0000-0002-1636-6467] - redaktorka i specjalistka ds. prostego języka w kancelarii Wardyński i Wspólnicy; przedstawicielka w Polsce organizacji Clarity propagującej prosty język w komunikacji prawniczej; zainteresowania badawcze: prosty język, język prawniczy, zrozumiałość tekstu. 
